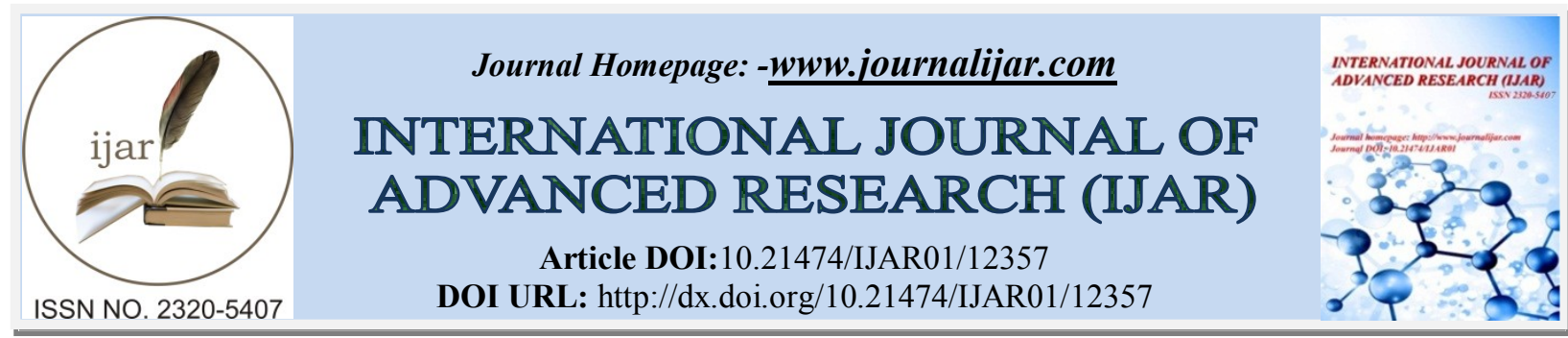

RESEARCH ARTICLE

\title{
PARK-PEOPLE CONFLICT IN BANGLADESH: A CASE STUDY FROM CHUNATI WILDLIFE SANCTUARY AND DUDHPUKURIA-DHOPACHORI WILDLIFE SANCTUARY
}

\author{
Jime Roy ${ }^{1}$ and A.H.M. Raihan Sarker ${ }^{2}$ \\ 1. Research Officer, Bangladesh Forest Research Institute, Ministry of Environment, Forest and Climate Change. \\ 2. Associate Professor, Institute of Forestry and Environmental Sciences, University of Chittagong.
}

\section{Manuscript Info}

.1.........................

Manuscript History

Received: 25 November 2020

Final Accepted: 28 December 2020

Published: January 2021

Key words: -

Conflict, Wildlife-Human Interaction,

Perception, Protected Area

\section{Abstract}

Conflict between people and wildlife is a foremost issue for conservation which is hard to solve when the wants of people collide in a straight line with the needs of endangered species like wild elephant. This study was carried out in the adjoining villages of two protected areas (PAs) of Chittagong region namely Dudupukuria-Dhopachori Wildlife Sanctuary (DDWS) and Chunati Wildlife Sanctuary (CWS) to identify the attitude of the villagers to the PAs by measuring different received benefits and faced problems from those reserves, the interaction between human and wild elephants and the opinions of the villagers to the effectiveness of community based wildlife management. The data were collected through a quantitative household survey which includes a series of close ended, fixed response and simple questions. Crop depredation was identified as a major problem to the villagers and they received small amount of benefits for the conservation program through protected area which create negative attitude among them to the PAs. Though most of the people were willing to participate in community based conservation program, they didnot think that such kind of approach is effective to protect biodiversity in the PAs. The present study makes the recommendation to build positive attitude to the PAs, to minimize the conflict, helps in future planning programs and further research of this field.

Copy Right, IJAR, 2021. All rights reserved.

\section{Introduction:-}

Conflict may be a disagreement through which the people involved perceive a threat to their requirements, interests or concerns (Wikipedia 2013). Park-people conflict generally occurs due to the restrictions in resource collection and uses. Rural villagers in many developing countries are vulnerable to the establishment of protected areas (PAs), as they depend primarily on locally available sources for their livelihood and spiritual needs (Gadgil 1990, Saberwalet al. 1994, Nepal and Weber 1995, Maikhuriet al. 2001). In developing countries, like Bangladesh, with rapid growth of population and demand for fuel wood and fodder, conflicts are likely to occur. Therefore, PAs which contain resources no longer in the buffer zone (Heinen 1993, Straede and Helles 2000). Most of the PAs in south Asian and Trans-Himalayan region (Bhutan, India, Nepal, North-east Pakistan and Southern Tibet) support various forms of land use such as agriculture, livestock grazing and in collection of minor forest products (Mcneely and Scherr 2003). The creation of PAs alters land use rights in general (Agarwal and Ostram 2001, Jim and Xu 2003, Panusittikorn and Patro 2001, Roth 2004, Wilshusenet al. 2002). Negative impression towards PA was raised 
by restricted access and use of natural resources through legislation, enforcement and privatization (Greenhog 2003, Horowitz 1998, Igoe 2003, Mahanty 2003, Negi and Nautiyal 2003, Santana 1991). Thus, conflict is often found at the heart of PA establishment and maintenance (West et al. 2006). Moreover, traditional forest management knows how to manage the resource but not the people (Gilbert 1971). Hence, PAs, as with any development intervention, are also instrumental influencing social conflicts between groups (West et al. 2006) as to observe between rich and poor, (Mclean and Streade 2003), castes (Paudal 2005), ethnic groups (Nelson and Hossack 2003) and between the people and wildlife, living adjacent to park areas (Limbu and Karki 2003).

The conflict between park authority and local people for wildlife conservation is one of the most common problems throughout the developing world (Mishra 1984). Crop damage and depredation of livestock are the major cause of conflict as reported in several studies (Kharel 1997, Mishra 1997, Saberwalet al. 1994 and Shekhar 1998). Whenever, wildlife causes serious damages to human livelihoods, a common response has been taken to kill them which is called "Lethal Control" or "Persecution" (Woodroffeet al. 2005). Thus, the conflict between people and wildlife is a major conservation issue that is difficult to resolve. It is difficult to decide what to do when the needs of people clash so directly with the needs of threatened species (Limbu and Karki 2003). Therefore, the conflict between wildlife and people is an important factor affecting the relationship between PAs and the people who live near them (Stubsrod and Wegge 1995, Hill 1998).

In Bangladesh, PAs are facing park-people conflict for several years. People have been denied the right access to utilize the resources inside the reserves. Similarly, human settlements in surrounding areas of reserves also pose critical disturbance to the reserves. Thus, it is becoming a matter of conflict between reserve authorities and local people living adjoining areas. Hence, involving local people in conservation planning and decision making process is important. The attitudes and feelings of park surrounding people concerning conservation policies and conflicts with wildlife affect their behaviour (Wang et al. 2006). Conservation policies that restrict traditional land uses and/or increases losses of livestock, crops and human in and around the park surrounding villages due to wildlife conservation will cause antagonistic feelings in the people who once were stewards of the land (Mordi 1991, Mehta and Kellert 1998, Conovor 2002). Negative attitudes are linked to various causalities including loss of resources, use rights, livestock depredation and crop damage, lack of compensation strategies and exclusion of farmers from the park's planning process. In other hand, the positive attitudes associated with an expectation that significant economic benefits would be available from the park. The benefits may be the empowerment of local communities associated with monetary benefits from non-timber forest products and compensation for loss of crops and livestock (Wang et al. 2006). These benefits motivate them to look after the resources and reduce the conflicts with wildlife (Sarker and Røskaft 2010). Hence, understanding human attitudes and the potential for wildlife conflicts in the context of PA management is critically important (Heinen 1993, Mordi 1991).

Crop raiding by wild animals, especially wild elephants is one of the most significant sources of park-people conflict (Nyphuset al. 2000). Wild animals that traditionally lived in forests now frequently come out in groups or as scattered individuals and cause financial and social losses (Sukumer 1989, Thouless 1994). In the most of the time the losses are crop damage and injury or death to people (Hoare 2000). As human population increases and population of many animal species become more concentrated in isolated PAs and remnant forest habitats. Combined actions with the local communities and administration can guarantee the nutriment as well as reduce the conflict between the human and wildlife. If we fail to appreciate these crucial facts, we can never fully understand the causes of conflicts, and will never successfully resolve conflict (Woodroffeet al. 2005).

Chittagong and Chittagong Hill Tracts (CHTs) are very rich in flora and fauna (Khan et al. 2007) which provide the sufficient diet and shelter for many valuable wildlife and majority of the immigrant poor, landless people and Rohingya (Citizen of Myanmar) has been settled in Chittagong region. These immigrant people are rehabilitated surrounding the forest areas as well as PAs (Sarker and Røskaft 2010) and increasing the chance of conflict between human and wildlife. However, only few literatures available on park-people conflict in the context of Bangladesh. Therefore, an attempt has been made to explore the interaction between local people and wild animals and the influence of such interaction on the relationship between park and people. The overall aim of this thesis was to evaluate the existing conflicts between people and protected areas (PAs) in Chittagong region. Considering the aim of the study, the major objectives are as follows:

1. to identify the benefits and problems of PA conservation and the ways that people perceive conservation programmes;

2. to explore the interactions between humans and wildlife in protected areas; and 
3. to test the perception of local people towards PA conservation and management through community participation.

\section{Materials andMethods: - Study areas:}

We worked in the two protected areas (PAs) [i.e. Chunati Wildlife Sanctuary (CWS) and Dhudpukuria-Dhopachari Wildlife Sanctuary (DDWS)] in the Chittagong region which are situated in the south-eastern part of the Bangladesh (Figure 1). According to Wildlife Conservation Act 1974, these areas are closed to hunting, shooting or trapping of wild animals and being considered as undisturbed breeding ground primarily for the protection of wildlife inclusive of all natural resources such as vegetation, soil and water. The CWS was established in $18 \mathrm{March}, 1986\left(21^{\circ} 58^{\prime} \mathrm{N}\right.$, $92^{0} 04^{\prime} \mathrm{E}$, total area $7763.97 \mathrm{ha}$ ) and has been managed by the wildlife and nature conservation division, Chittagong. The DDWS was established in 6 may, $2010\left(22^{0} 19^{\mathrm{N}} \mathrm{N}, 92^{0} 08^{\prime} \mathrm{E}\right.$; total area 4716.57 ha) and has been managed by the Chittagong Forest Division (South). The sanctuary areas are generally hilly with shallow to deep gullies and gentle to steep slope, traversed by numerous streams. Seven villages were selected randomly from DDWS (i.e., Fakirtila, Tilokmardhorpara, Napitpukuria, Sukhbilash, Kolaharia, Dudhpukuria and Borsonkola) while four villages from CWS (i.e., Jumpara, Kolatoli, Uttar Harbang and PoschimBrindaboni (Figure 1).

\section{Literature Review:-}

Intensive literature review was done to understand the human-wildlife interaction in the protected areas and to identify the factors controlling the people's perception towards the conservation of protected areas. we filtered the factors which influenced the perception of people on the road to conservation of parks and wild animals. Distance from the PA boundary, land ownership, settlement status, occupation and ethnicity of the respondents played a vital role in forest protection. Gender, family size even the marital status also acted as effective influencing factors in this purpose. Age, level of education and financial rank of the respondents played a critical function in the public's philosophy toward the conservation of PA and wildlife.

\section{Sampling and data collection:}

The respondents were from 11 villages under 3 unions and 3 sub-districts across the two study sites. In this study, people who were born in there and possess land right heretically in the areas was defined by the word "Local" and who have migrated to the vicinity of the study areas beginning in the early 1980s and who didn't get land right heretically are defined as "Immigrants". The interview included a series of close-ended (experience of villagers with nearby forest and wildlife) and fixed-response questions (attitude statements) (Box 1). During the interview, more concrete and simple questions following the everyday terms people were included in the questionnaire used to describe benefits and problems from PAs and then extracted their attitude towards the PAs from their responses. The respondents' opinion about the attitude statements were recorded as yes/no or agree/disagree. If the respondent said 'no' to a positive statement, no point was given. The reverse was true for a negative statement. A series of supplementary questions were included in the interview to gather the demography information at the individual respondent level. During the data collection, household maps were prepared in each study sites using a Global Positioning System (GPS) device. The demographic features of each village in the study area were collected from the local union council. A total of 195 (95 from DDWS and 100 from CWS) standardized, structured and semistructured questionnaires was administrated to the villagers over the age of 18 years. The participants were selected randomly, and completion of questionnaires was facilitated through "face to face" communication tools. Usually household heads were interviewed mostly; however, in their absence, any member willingly to participate was interviewed. The respondents were chosen for interview on the basis on their income [i.e., poor $(\mathrm{BDT}<5000)$, medium (BDT 5000-10000) and rich (BDT > 10000)]. The collected data were further categorized into occupation (Farmer and non-farmer), education (illiterate, primary, Illiterate), settlement status (local or immigrant), age (young i.e. $<31$ yrs; middle age i.e. 31-50 yrs; old i.e. $>50$ yrs) and Family size (small size i.e. up to 5 members and Large size i.e. $>5$ members). In this study, we defined both daily labourers and other occupations as "non-farmer".

\section{Data Analysis: -}

Data were analysed using SPSS (statistical package for social science) windows version 16.0. Perceptions were related to many demographic variables. Here, $\mathrm{p}<0.05$ was set as the significance level. Differences between perceptions were tested using Pearson's Chi-square $\left(\chi^{2}\right)$ test. Step wise linear regression was used to investigate the relationships between perceptions and different independent variables. 
Box 1:- The close ended questions and statements presented to respondents to assess their attitude or perception.

1. Questions presented to respondents to assess their perceptions towards the PAs

A. Have you received any benefit from financial incentives and soft credit? (small amount/large amount)

B. Have you received any benefit from training and information on wild life and nature? (small amount/large amount)

C. Have you received any benefit from the sound environment and tourism business? (small amount/large amount)

D. Have you faced any problem from the PA? (small amount/large amount)

2. Questions presented to respondents to asses their perceptions of human-wild animal conflict
A. Which wild animal cause damage crops?
B. Are you able to control wildlife damages to your property? (no/yes)
C. How do you consider such damage? (negligible/much/very much)
D. Does the conflict between wild elephant and human increases? (no/yes)

3. The statements presented to respondents to assess their perception to the effectiveness of community based wildlife management (CBWM):

A. CBWM can improve the regeneration status of trees (disagree/agree).

B. CBWM can increase the range of wildlife habitat (disagree/agree).

C. CBWM can reduce the rate of illicit felling of trees and killing of wildlife (disagree/agree). 


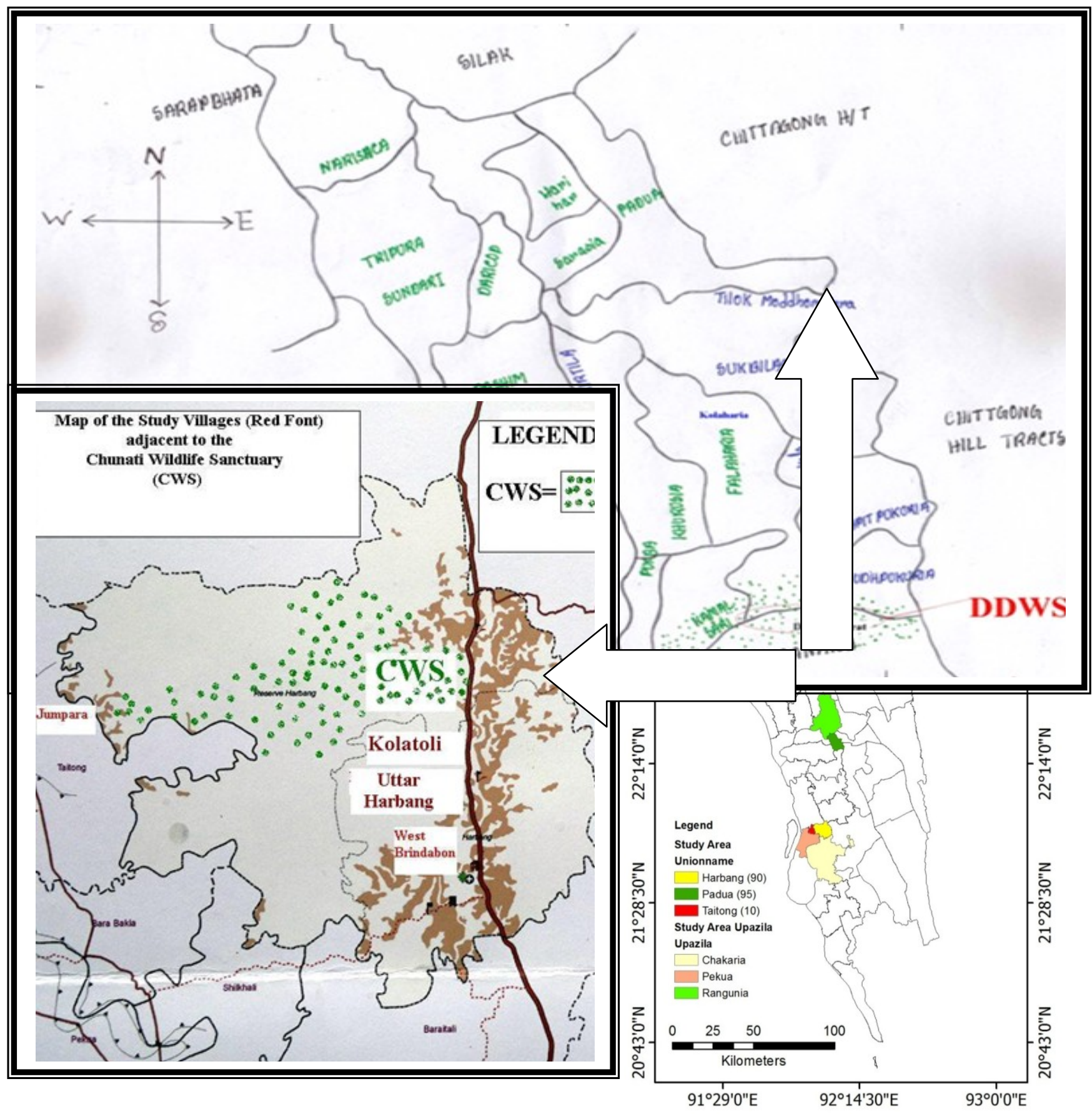

Results: -

Demographic and Socio-economic analysis:

The demographic and socio-economic characteristics varied significantly in most cases between the study sites (Table 1). The results of the study revealed that the education, occupation, monthly income and settlement status of the respondents varied considerably among the study sites, but insignificant with age class and household size (Table 2). Majority of the respondents were educated and their proportion was considerably higher around the Dhudpukuria-Dhopachari Wildlife Sanctuary (DDWS) compared to the Chunati Wildlife sanctuary (CWS). No respondents were educated in the Jumpara village, while literacy rate was absolutely higher in the Fakirtila, TilokModdhomPara, Sukhbilash, Kolaharia and Kolatoli villages and literacy rate statistically different between study sites $\left(\chi^{2}=54.24, \mathrm{df}=10, p=0.0001\right)$. Agricultural farming was the major occupation across the study sites and the proportion of farmer was higher around the DDWS and lower near the CWS. Among the villages studied, the 
proportion of farmers was higher in Napitpukuria (97.0\%) and lower in Uttar-Harbang, $\left(61.9 \%, \chi^{2}=37.99\right.$, df=10, $p=0.0001)$.

Table 1: - Demographic and socio-economic features obtained from interviews (see text for details), for the 195 households around the two protected areas and $\chi 2$ tests of independence between the study areas. Table shows the number (n) and percentage (\%) in bracket.

\begin{tabular}{|c|c|c|c|c|c|c|c|}
\hline \multirow{2}{*}{\multicolumn{2}{|c|}{ Variables }} & \multicolumn{3}{|c|}{ Study areas } & \multirow{4}{*}{$\begin{array}{l}\chi^{2} \\
4.57\end{array}$} & \multirow{4}{*}{$\begin{array}{r}\text { df } \\
2\end{array}$} & \multirow{4}{*}{$\begin{array}{l}p \\
0.102\end{array}$} \\
\hline & & & & & & & \\
\hline \multirow{3}{*}{ Age } & Young $(<$ than 31 yrs $)$ & \multirow{2}{*}{\begin{tabular}{|r|}
$\begin{array}{l}\text { DDWS } \\
(\mathbf{n = 9 5})\end{array}$ \\
$8(8.4)$ \\
$61(64.2)$
\end{tabular}} & \multirow{2}{*}{$\begin{array}{c}\begin{array}{l}\text { CWS } \\
(\mathbf{n}=\mathbf{1 0 0})\end{array} \\
19(19.0) \\
57(57.0)\end{array}$} & \begin{tabular}{|l|l}
$\begin{array}{l}\text { Total } \\
(\mathbf{n}=\mathbf{1 9 5})\end{array}$ \\
$27(13.8)$ \\
\end{tabular} & & & \\
\hline & Middle age ( 31 to $50 \mathrm{yrs}$ ) & & & $118(60.5)$ & & & \\
\hline & Old $(>50 \mathrm{yrs})$ & $26(27.4)$ & $24(24.0)$ & $50(25.6)$ & & & \\
\hline \multirow[t]{2}{*}{ Education } & Illiterate & $23(24.2)$ & $40(40.0)$ & $63(32.3)$ & \multirow[t]{2}{*}{5.55} & \multirow[t]{2}{*}{1} & \multirow[t]{2}{*}{0.018} \\
\hline & literate & $72(75.8)$ & $60(60)$ & $132(67.7)$ & & & \\
\hline \multirow[t]{2}{*}{ Occupation } & Farmer & $85(89.5)$ & $66(66.0)$ & $151(77.4)$ & \multirow[t]{2}{*}{15.36} & \multirow[t]{2}{*}{1} & \multirow[t]{2}{*}{0.0001} \\
\hline & Non-Farmer & $10(10.5)$ & $34(34.0)$ & $44(22.6)$ & & & \\
\hline \multirow[t]{2}{*}{ Household size } & Small Size $(<5$ members $)$ & $55(57.9)$ & $49(49.0)$ & $104(53.3)$ & \multirow[t]{2}{*}{1.55} & \multirow[t]{2}{*}{1} & \multirow[t]{2}{*}{0.135} \\
\hline & Large Size ( $>5$ members) & $40(42.1)$ & $51(51.0)$ & $91(46.7)$ & & & \\
\hline \multirow[t]{3}{*}{ Income } & Poor (BDT 5000) & $42(44.2)$ & $26(26.0)$ & $68(34.9)$ & \multirow[t]{3}{*}{8.46} & \multirow[t]{3}{*}{2} & \multirow[t]{3}{*}{0.014} \\
\hline & Medium (BDT 5100- 10000) & $46(48.4)$ & $58(58.0)$ & $104(53.3)$ & & & \\
\hline & Rich $(>10000)$ & $7(7.4)$ & $16(16.0)$ & $23(11.8)$ & & & \\
\hline \multirow{2}{*}{$\begin{array}{l}\text { Settlement } \\
\text { status }\end{array}$} & Local & $66(69.5)$ & $7(7.0)$ & $73(37.4)$ & \multirow[t]{2}{*}{81.18} & \multirow[t]{2}{*}{1} & \multirow[t]{2}{*}{0.0001} \\
\hline & Immigrant & $29(30.5)$ & $93(93.0)$ & $122(62.6)$ & & & \\
\hline
\end{tabular}

Majority of the respondents were belonged to medium income group and their proportion was higher in the villages near the CWS while lower in the villages around DDWS. Among the financially poor respondents, majority of them were resided around the DDWS. In DDWS, the proportion of poor respondents was higher in TilokModdhomPara $(100.0 \%)$ and the lower in Sukhbilash and Kolaharia $\left(0.00 \%, \chi^{2}=40.442, \mathrm{df}=20, p=0.004\right)$. Almost two-thirds of the respondents were immigrant across the study areas and their proportion was higher in the villages surrounded by the CWS and lower in villages around the DDWS. Among the study villages, the proportion of the immigrants was higher in Jumpara, Kolatoli and Uttar-Harbang villages located around the CWS compared to other villages across the study sites $\left(1000 \%, \chi^{2}=92.32, \mathrm{df}=10, p=0.0001\right)$.

\section{Benefits of protected areas:}

We have considered four kinds of benefits in order to understand the perceptions of respondents towards the conservation of DDWS and CWS. These are: (i) benefit from timber and fire wood, (ii) benefit from financial incentives and soft credit, (3) benefit from training and information on wildlife and nature and (4) benefit from the sound environment and tourism business. The perceptions of respondents towards those benefits as mentioned above varied significantly between study sites (Table 2). Majority of the respondents reported that the conservation programme through protected area provided small benefit with timber and firewood $(64.1 \%)$, financial incentives and soft credit $(91.28 \%)$, training and information on wildlife and nature $(78.46 \%)$ and sound environment and tourism business $(91.28 \%)$. The proportion of respondents received large amount of benefits from financial incentives and soft credit, training and information on wildlife and nature, and sound environment and tourism business were considerably higher in the villages near the CWS compared to those villages located around the DDWS, while the opposite scenario observed in CWS where very few respondents claimed that they perceived small amount of benefit from timber and firewood than those respondents inhabited around DDWS. Local people $(\mathrm{n}=44,62.9 \%)$ obtained large amount of benefit from timber and fire wood than that of immigrant people and their perception varied significantly $\left(\chi^{2}=30.13, \mathrm{df}=1, p=0.0001\right)$. The findings of the study showed that immigrant people received large amount of benefit from information and training on wildlife and nature $(\mathrm{n}=42,100.0 \%)$ and than that of the local people $\left(\chi^{2}=32.030, \mathrm{df}=1, p=0.0001\right)$. Immigrant people $(\mathrm{n}=15,88.2 \%)$ also claimed large amount of benefit from sound environment and tourism business than that of the local people reported $\left(\chi^{2}=5.24\right.$, df $=1, p=0.022$ ). The results of the study revealed that there was significant variation in perceptions of respondents towards different kinds of benefits across the study villages $\left(\chi^{2}\right.$ Timber and firewood $=1.009, \mathrm{df}=10, p=0.0001, \chi^{2}$ Financial incentives and soft credit $=21.79, \mathrm{df}=10, p=0.016, \chi^{2}$ Training and wildlife-nature information $=62.77, \mathrm{df}=10$, $p=0.0001$, and $\chi^{2}$ Sound environment and tourism $=24.20, \mathrm{df}=10, p=0.007$ ). The results of the study indicated that 
among the studied villages, the percentage of respondents received large amount of benefits from timber and firewood was higher in Kolaharia (100.0\%), while respondents who lived in Kolatoli and PoschimBrindabonivillages reported no benefit. Majority of the respondents $(90.0 \%)$ resided in Jumpara reported that they received more benefit from training and information on wildlife and nature compared to other villages.

Table 2:- The number and the percentage of the respondents related to the benefits from DDWS and CWS and $\chi^{2}$ tests of independence between the study areas.

\begin{tabular}{|c|c|c|c|c|c|c|c|}
\hline \multirow{2}{*}{\multicolumn{2}{|c|}{ Benefits }} & \multicolumn{3}{|c|}{ Study areas } & \multirow[t]{2}{*}{$\chi^{2}$} & \multirow[t]{2}{*}{ df } & \multirow[t]{2}{*}{$p$} \\
\hline & & \multirow{2}{*}{$\begin{array}{c}\begin{array}{c}\text { DDWS } \\
(\mathbf{n}=95)\end{array} \\
35(36.80)\end{array}$} & \multirow{2}{*}{$\begin{array}{c}\begin{array}{c}\text { CWS } \\
(\mathbf{n}=\mathbf{1 0 0})\end{array} \\
90(90.0)\end{array}$} & \multirow{2}{*}{$\begin{array}{c}\begin{array}{c}\text { Total } \\
(\mathbf{n}=\mathbf{1 9 5})\end{array} \\
125(64.10)\end{array}$} & & & \\
\hline \multirow[t]{2}{*}{ Timber \& firewood } & Small amount & & & & \multirow[t]{2}{*}{59.82} & \multirow[t]{2}{*}{1} & \multirow[t]{2}{*}{0.0001} \\
\hline & Large amount & $60(63.2)$ & $10(10.0)$ & $70(35.9)$ & & & \\
\hline \multirow{2}{*}{$\begin{array}{l}\text { Financial incentives \& soft } \\
\text { credit }\end{array}$} & Small amount & $93(97.9)$ & $85(85.0)$ & $178(91.28)$ & \multirow[t]{2}{*}{10.18} & \multirow[t]{2}{*}{1} & \multirow[t]{2}{*}{0.001} \\
\hline & Large amount & $2(2.1)$ & $15(15.0)$ & $17(8.72)$ & & & \\
\hline \multirow{2}{*}{$\begin{array}{l}\text { Training \& information on } \\
\text { wildlife \& nature }\end{array}$} & Small amount & $94(98.9)$ & $59(59.0)$ & $153(78.46)$ & \multirow[t]{2}{*}{46.0} & \multirow[t]{2}{*}{1} & \multirow[t]{2}{*}{0.0001} \\
\hline & Large amount & $1(1.1)$ & $41(41.0)$ & $42(21.52)$ & & & \\
\hline \multirow{2}{*}{$\begin{array}{l}\text { Sound environment \& tourism } \\
\text { business }\end{array}$} & Small amount & $93(97.9)$ & $85(85.0)$ & $178(91.28)$ & \multirow[t]{2}{*}{10.18} & \multirow[t]{2}{*}{1} & \multirow[t]{2}{*}{0.001} \\
\hline & Large amount & $2(2.1)$ & $15(15.0)$ & $17(8.72)$ & & & \\
\hline
\end{tabular}

\section{Problems:}

Among the problems associated with the DDWS and CWS perceived by the respondents was crop raiding by wild animals. The proportion of respondents, who faced large amount of crop raiding caused by wild elephants were higher in DDWS (82.2\%) compared to CWS (17.5\%) and their perceptions towards crop raiding problem caused by wild elephant varied significantly across the study sites $\left(\chi^{2}=42.61, \mathrm{df}=1, p=0.0001\right)$. Crop damage by wild elephants with other animals (such as monkey, rat, and bird) was reported in DDWS but no respondents replied such in CWS. Among the studied villages, large amount of crop raiding was reported by the respondents who lived in Dudhpukuria village near the DDWS $\left(33.3 \%, \chi^{2}=56.46, \mathrm{df}=10, p=0.0001\right)$. Moreover, poor people $(\mathrm{n}=30,47.60 \%)$ faced large amount of crop raiding by wild elephants from PAs than that of the medium $(\mathrm{n}=27,42.9 \%)$ and rich people $(n=6,9.5 \%)\left(\chi^{2}=6.66, d f=2, p=0.036\right)$. Literate people $(n=65,59.63 \%)$ objected mostly that wild elephants were responsible for damage occurred in the villages adjacent to the PAs than that of the illiterate people $\left(40.40 \%, \chi^{2}=15.56, \mathrm{df}=6, p=0.016\right)$. Farmers also claimed typically $(\mathrm{n}=75,68.8 \%)$ that wild elephants caused the damages in the study sites than that of the non-farmers $\left(31.2 \%, \chi^{2}=21.37, \mathrm{df}=6, p=0.002\right)$ while immigrant people $(\mathrm{n}=96,88.10 \%)$ reported elephants' damage mostly compared to the local people $(\mathrm{n}=13,11.9 \%)\left(\chi^{2}=\right.$ $75.53, \mathrm{df}=6, p=0.0001)$. More than half of the respondents $(59.5 \%)$ reported that wild animals raided paddy field and the intensity of crop raiding was higher in villages near DDWS than those villages near CWS $\left(\chi^{2}=80.09\right.$, $\mathrm{df}=4$, $p=0.0001)$. More than two-third of the respondents $(82.1 \%)$ reported that crop damage caused by wild elephants occurred all time of the year in DDWS while in CWS during the dry season $\left(\chi^{2}=1.77, \mathrm{df}=1, p=0.0001\right)$.

\section{Ability to control damage:}

Majority of the respondents $(75.9 \%)$ reported that they were unable to control the damages caused by different wildlife that include wild elephants and their ability to control such damage varied considerably between study sites $\left(\chi^{2}=28.44, \mathrm{df}=3, p=0.0001\right)$. The ability of respondents to control the damage caused by wild animals was higher in villages near CWS (39.0\%) and lower in villages around DDWS. More than two third of the respondents $(68.2 \%)$ reported that they considered the crop damage caused by wildlife as negligible $\left(\chi^{2}=28.44, \mathrm{df}=3, p=0.0001\right)$.

\section{Peoples experiences with the conflict:}

The findings of the study also revealed that the intensity of human-elephant conflict varied significantly between the study sites $\left(\chi^{2}=15.87, \mathrm{df}=1, p=0.0001\right)$. Almost all respondents $(93.1 \%)$ reported that the conflict between human and wild elephants was increased in their villages surrounded by the park. Among the respondents, immigrants $(\mathrm{n}=$ $116,66.3 \%)$ reported more about human-elephant conflict compared to the local people $(\mathrm{n}=79,33.7 \%)\left(\chi^{2}=9.725\right.$, $\mathrm{df}=1, p=0.002)$. 
Factors contributing to the people's perception towards benefits and problems of protected areas: Benefit from timber and firewood:

A stepwise linear regression analysis was applied to examine the perception of the respondents towards whether benefit from timber and firewood was taken as dependent variable and tested with six independent variables. This analysis showed that the settlement status and income of the household were the most significant factors contributing to the variation in this perception. All independent variable explained $19.3 \%$ of the variation in people's perception of benefit from the timber and firewood. The findings of the analysis revealed that local people get higher benefit from timber and firewood than that of the immigrant people while poor people reported more benefit from timber and firewood than rich people. Other four variables were insignificant to explain the variation in perception related to the benefit of timber and firewood (Table 3).

\section{Benefit from training and information on wildlife and nature:}

To test how much of the variation was explained by six independent variables with perception on benefit from training and information on wildlife and nature was used as dependent variable in a stepwise linear regression analysis. Except the occupation of the respondents, all other variables were contributing significantly to explain the variation in perception. All independent variables showed $25.7 \%$ of the variation in people's perception on benefit from training and information on wildlife and nature. The most explanatory variable was settlement status. The second most important predictor was age. Then education of the respondents, income of the household and household size arrived consequently. The analysis expressed that immigrant respondents reported higher level of benefit from training and information on wildlife and nature than that of the local people while respondents, who were from large sized family and had rich income status reported large amount of benefit compared to the respondents of small sized family and poor people. The young and illiterate people also expressed higher level of benefit of training and information on wildlife and nature than those of old and literate people reported (Table 3).

\section{Benefit from financial incentives and soft credit:}

A stepwise linear regression was used to explain variations in perception of respondents towards whether benefit from financial incentives and soft credit was considered as dependent variable and tested with six independent variables (Table 3). Except the settlement status of the respondents, other five variables were insignificant to explain the variation in perception related to the benefit of financial incentives and soft credit. All dependent variables showed $2.7 \%$ of the variation in people's perception on benefit from financial incentives and soft credit. The analysis showed that immigrant people got higher benefit from financial incentives and soft credit than that of the local people.

\section{Benefit from sound environment and tourism business:}

We tested the perception of the respondents towards the benefit from sound environment and tourism business as a dependent variable with six independent variables in a stepwise linear regression analysis (Table 3). Thesettlement status and age of the respondents were significant contributors to explain the variation. All independent variable explained $2.7 \%$ of the variation in people's perception of benefit from sound environment and tourism business. The analysis indicated that immigrant respondents feel more benefited from sound environment and tourism business than that of the local people while old aged respondents felt it more than that of the young people. Other four variables were insignificant to explain the variation in perception related to the benefit from sound environment and tourism business.

Table: 3:- Results of stepwise linear regression with perceptions as dependent variables in relation to various independent variables $(\mathrm{R}=$ rank, $\mathrm{t}=\mathrm{t}$-value $)$

\begin{tabular}{|c|c|c|c|c|c|c|c|c|c|c|c|c|}
\hline \multirow[t]{2}{*}{$\begin{array}{l}\text { Independent } \\
\text { variables }\end{array}$} & \multicolumn{3}{|c|}{$\begin{array}{l}\text { Benefit from timber } \\
\& \text { firewood }\end{array}$} & \multicolumn{3}{|c|}{$\begin{array}{c}\text { Benefit from } \\
\text { training \& } \\
\text { information on } \\
\text { wildlife \& nature }\end{array}$} & \multicolumn{3}{|c|}{$\begin{array}{l}\text { Benefits from } \\
\text { financial incentives } \\
\& \text { soft credit }\end{array}$} & \multicolumn{3}{|c|}{$\begin{array}{l}\text { Benefit from the } \\
\text { sound environment } \\
\text { \& tourism business }\end{array}$} \\
\hline & $\mathbf{R}$ & $\mathbf{t}$ & $p$ & $\mathbf{R}$ & $\mathbf{t}$ & $p$ & $\mathbf{R}$ & $\mathbf{t}$ & $p$ & $\mathbf{R}$ & $\mathbf{t}$ & $p$ \\
\hline Household size & 5 & -0.645 & 0.52 & 5 & 2.07 & 0.04 & 6 & -0.067 & 0.947 & 3 & -1.019 & 0.31 \\
\hline Income of HHs & 2 & -2.139 & 0.034 & 4 & 2.113 & 0.036 & 4 & 0.3 & 0.765 & 4 & 0.491 & 0.624 \\
\hline Occupation & 6 & -0.361 & 0.719 & 6 & 0.495 & 0.621 & 3 & -0.84 & 0.402 & 5 & 0.396 & 0.693 \\
\hline $\begin{array}{l}\text { Settlement } \\
\text { status }\end{array}$ & 1 & -5.943 & 0.0001 & 1 & 5.695 & 0.0001 & 1 & 2.309 & 0.022 & 1 & 2.309 & 0.022 \\
\hline Education & 3 & -1.284 & 0.201 & 3 & -2.419 & 0.016 & 5 & 0.111 & 0.912 & 6 & 0.233 & 0.816 \\
\hline
\end{tabular}




\begin{tabular}{|l|r|r|r|r|r|r|r|r|r|r|r|r|}
\hline Age & 4 & 1.147 & 0.253 & 2 & -2.516 & 0.013 & 2 & -1.193 & 0.234 & 2 & 2.308 & 0.043 \\
\hline Constant & 3 & 11.224 & 0.0001 & 4 & 3.897 & 0.0001 & 2 & 13.237 & 0.0001 & 2 & 13.273 & 0.0001 \\
\hline $\mathrm{R}^{2}$ & & 0.193 & 0.0001 & & 0.257 & 0.0001 & & 0.027 & 0.022 & & 0.027 & 0.022 \\
\hline
\end{tabular}

Problems of crop raiding by wild animals:

A step wise linear regression had been done to test the people's perception of crop raiding problem caused by wild animals as dependent variable with six independent variables (Table 4). All independent variables were explained $2.6 \%$ of the variation in people's perception related to the crop raiding problem. The findings of the analysis showed that only income of the households contributed significantly to explain the variation. It expressed that poor respondents reported higher level of crop raiding by wild animals than that of the medium and rich respondents did. All other variables were insignificant to explain the variation in perception.

\section{Crop damaged by wild animals:}

The variable explaining the most variation in this perception was the settlement status of the respondent. Income of the household was the second most important predictor. Other variables were insignificant to explain the variation in perception related to the crop damage by wild animals. All independent variable explained $8.3 \%$ of the variation in people's perception of crop damaged by wild animals (Table 5). The regression analysis expressed that local people claimed higher level of wild animals' crop raiding than that of the immigrant people. Poor people reported more crop damage caused by wild animals than that of the rich people did.

Table: 4:- Results of stepwise linear regression with perceptions as dependent variables in relation to various independent variables $(\mathrm{R}=$ rank, $\mathrm{t}=\mathrm{t}$-value $)$.

\begin{tabular}{|c|c|c|c|}
\hline \multirow[t]{2}{*}{ Independent variables } & \multicolumn{3}{|c|}{ Problems of crop raiding by wild animals } \\
\hline & $\mathbf{R}$ & $\mathbf{t}$ & $p$ \\
\hline Household size & 5 & -0.764 & 0.446 \\
\hline Income of the $\mathrm{HHs}$ & 1 & -2.272 & 0.024 \\
\hline Occupation & 4 & -1.139 & 0.256 \\
\hline Settlement status & 3 & -1.73 & 0.085 \\
\hline Education & 2 & 1.919 & 0.056 \\
\hline Age & 6 & -0.3 & 0.764 \\
\hline Constant & 1 & 15.738 & 0.0001 \\
\hline $\mathrm{R}^{2}$ & & 0.026 & 0.024 \\
\hline
\end{tabular}

\section{Ability to control crop damage:-}

The stepwise linear regression represented that income of the household and settlement status was the significant variable contributing to the people's perception in ability to control crop damage (Table 5). Financially solvent people showed higher level of ability to control crop damage than that of the poor people where immigrant people put upper level of ability compared to the local people. Other variables were insignificant to explain the variation in perception related to the ability to control damage. All independent variable explained $9.3 \%$ variation in people's perception.

\section{Attitude to the crop damage:-}

The linear regression analysis showed that only income of the household varied considerably in the People's attitude towards the crop damage (Table 5). Other variables were insignificant to explain the variation in perception related to the attitude to the crop damage. All independent variables explained $7.0 \%$ of the variation in the people's perception. Poor people expressed lower level of tolerance towards the crop damage than that of the rich people.

\section{The perception is whether conflict is increasing:-}

The regression test revealed that only the settlement status of the respondents contributed significantly in the explaining of people's perception of whether conflict is increasing or not. Other variables were insignificant to explain the variation in perception related to the increase of conflict. All independent variable explained $5.2 \%$ of the variation in people's perception (Table 5). Immigrant people reported higher level of human wildlife conflict than that of the local people. 
Table 5:- Results of stepwise linear regression with perceptions as dependent variables in relation to various independent variables $(\mathrm{R}=$ rank, $\mathrm{t}=\mathrm{t}$-value).

\begin{tabular}{|c|c|c|c|c|c|c|c|c|c|c|c|c|}
\hline \multirow[t]{2}{*}{$\begin{array}{l}\text { Independent } \\
\text { variables }\end{array}$} & \multicolumn{3}{|c|}{$\begin{array}{l}\text { Crop damaged by } \\
\text { Wild animals }\end{array}$} & \multicolumn{3}{|c|}{$\begin{array}{l}\text { Ability to control } \\
\text { crop damage }\end{array}$} & \multicolumn{3}{|c|}{$\begin{array}{c}\text { Attitude to the crop } \\
\text { damage }\end{array}$} & \multicolumn{3}{|c|}{$\begin{array}{l}\text { Increasing human- } \\
\text { wildlife conflict }\end{array}$} \\
\hline & $\mathbf{R}$ & $t$ & $p$ & $\mathbf{R}$ & $t$ & $p$ & $\mathbf{R}$ & $\mathbf{t}$ & $p$ & $\mathbf{R}$ & $\mathbf{t}$ & $p$ \\
\hline Household size & 6 & -0.35 & 0.724 & 4 & -1.39 & 0.168 & 4 & -1.60 & 0.112 & 6 & -0.01 & 0.991 \\
\hline Income & 2 & -2.73 & 0.007 & 1 & 3.43 & 0.001 & 1 & 3.80 & 0.0001 & 4 & 0.47 & 0.638 \\
\hline Occupation & 3 & -1.86 & 0.065 & 6 & 0.54 & 0.584 & 6 & 0.31 & 0.758 & 2 & -1.22 & 0.225 \\
\hline Residential status & 1 & -3.13 & 0.002 & 2 & 2.73 & 0.007 & 3 & 1.74 & 0.084 & 1 & 3.18 & 0.002 \\
\hline Education & 4 & 1.60 & 0.112 & 5 & -0.75 & 0.455 & 5 & -1.34 & 0.182 & 5 & 0.11 & 0.915 \\
\hline Age & 5 & -0.74 & 0.463 & 3 & -1.58 & 0.116 & 2 & -1.77 & 0.078 & 3 & 1.19 & 0.237 \\
\hline Constant & 1 & 13.85 & 0.0001 & 4 & -2.37 & 0.019 & 3 & 5.47 & 0.0001 & 2 & 11.50 & 0.0001 \\
\hline $\mathrm{R}^{2}$ & & 0.083 & 0.0001 & & 0.09 & 0.0001 & & 0.07 & 0.0001 & & 0.052 & 0.002 \\
\hline
\end{tabular}

Attitude of respondents towards Pas:

The attitude of the respondents towards the conservation of PAs significantly varied between the study areas and among the villages (Table 6). The findings of the study showed that the respondents who lived near the DDWS expressed negative attitude mostly than that of the respondents who lived around the CWS. Among the respondents who showed negative attitude towards the conservation of PAs was higher in Dudhpukuria village near the DDWS. The respondents who lived in PoschimBrindabon village near the CWS showed more positive attitude towards conservation compared to the other villages across the study sites (Table 6).

Table 6:- The number and the percentage of the of respondents expressing negative and positive attitude to the DDWS and CWS in terms of the benefits and problems from the forest and $\chi^{2}$ tests of independence between the study areas and among the study villages.

\begin{tabular}{|c|c|c|c|c|c|c|}
\hline \multicolumn{2}{|l|}{ Variables } & \multicolumn{2}{|c|}{ Attitude of respondents towards PAs } & \multirow[t]{2}{*}{$\chi^{2}$} & \multirow[t]{2}{*}{ df } & \multirow[t]{2}{*}{$p$} \\
\hline & & Negative $(n=105)$ & Positive $(n=90)$ & & & \\
\hline \multirow[t]{2}{*}{ Study Area } & DDWS & $58(55.20)$ & $37(41.10)$ & \multirow[t]{2}{*}{3.871} & \multirow[t]{2}{*}{1} & \multirow[t]{2}{*}{0.049} \\
\hline & CWS & $47(44.80)$ & $53(58.9)$ & & & \\
\hline \multirow[t]{7}{*}{ DDWS } & Fakirtila & $4(3.80)$ & $2(2.20)$ & \multirow[t]{11}{*}{20.361} & \multirow[t]{11}{*}{10} & \multirow[t]{11}{*}{0.026} \\
\hline & TilokModdhom Para & $1(1.0)$ & $1(1.1)$ & & & \\
\hline & Napitpukuria & $19(18.10)$ & $14(15.60)$ & & & \\
\hline & Sukhbilash & $2(1.90)$ & $2(2.20)$ & & & \\
\hline & Kolaharia & $0(0)$ & $2(2.20)$ & & & \\
\hline & Borsonkola & $10(9.50)$ & $1(1.10)$ & & & \\
\hline & Dudhpukuria & $22(21.0)$ & $15(16.70)$ & & & \\
\hline \multirow[t]{4}{*}{ CWS } & Jumpara & $8(7.60)$ & $2(2.20)$ & & & \\
\hline & Kolaharia & $4(3.80)$ & $2(2.20)$ & & & \\
\hline & Uttar-Harbang & $12(11.40)$ & $9(10.0)$ & & & \\
\hline & PoschimBrindabon & $0(0)$ & $63(37.10)$ & & & \\
\hline
\end{tabular}

People's perception towards the community based conservation of protected areas:

The study revealed that more than half of the respondents (59.1\%) were willing to participate into community based protected area conservation scheme and their willingness varied considerably between the study sites $\left(\chi^{2}=76.97\right.$, $\mathrm{df}=1, p=0.0001)$. Among the respondents who were interested to participate in the community based conservation scheme, their proportion was higher in villages near CWS (91.9\%) compared to the villagers near DDWS (25.9\%).

\section{Improve the regeneration status:}

More than half of the respondents (52.1\%) agreed that community based conservation can improve the regeneration status of plants in the PAs and their perceptions varied significantly between study sites $\left(\chi^{2}=115.97, \mathrm{df}=1, p=\right.$ 0.0001). Respondents who lived near the CWS (89.9\%) agreed more about the improving regeneration status through community involvement in the conservation programme than that of respondents lived around DDWS (12.6\%). Similarly, literate people $(60.4 \%)$ than illiterate people $\left(39.6 \%, \chi^{2}=4.88, \mathrm{df}=1, p=0.027\right)$, farmers $(71.3 \%)$ than non-farmers $\left(28.7 \%, \chi^{2}=5.24, \mathrm{df}=1, p=0.022\right)$ and immigrant $(88.1 \%)$ than local people $\left(11.1 \%, \chi^{2}=59.51\right.$, df 
$=1, p=0.0001)$ agreed more about the potential role of community based conservation programme to improve the regeneration status of plants species in protected areas.

\section{Increase the range of wildlife habitat and wildlife population:}

Whenever we asked the respondents about the role of community based protected area conservation scheme in increasing the range of wildlife habitat as well as their population than majority of the respondents $(90.9 \%)$ reported that such conservation did not improve the situation in their nearest protected area, although their perception is insignificant $\left(\chi_{\text {RANGE OF WILDLIFE HABITAT }}^{2}=1.04, \mathrm{df}=1, p=0.039\right.$ and $\chi_{\text {RANGE OF WILDLIFE POPULATION }}^{2}=0.83, \mathrm{df}=1$, $p=0.362)$. The findings of study further revealed that the illiterate people $(58.8 \%)$ than literate people $(41.2 \%)$ agreed more about the increasing range of wildlife habitat and wildlife population in their nearest PA through community based conservation scheme $\left(\chi^{2}=5.56, \mathrm{df}=1, p=0.018\right)$. Illiterate people agreed mostly $(\mathrm{n}=9,64.3 \%)$ compared to the literate people $(\mathrm{n}=5,35.7 \%)$ with the perception of increase the range of wildlife population $\left(\chi^{2}=7.54, \mathrm{df}=2, p=0.023\right)$.

\section{Reduce the rate of illicit felling of trees and killing of wildlife:}

More than two-third of the respondents (73.4\%) disagreed with the effectiveness of community based conservation scheme to reduce the rate of illicit felling of trees and killing of wildlife and their perceptions varied considerably between the study sites $\left(\chi^{2}=60.1, \mathrm{df}=1, p=0.0001\right)$. Among the respondents who agreed that community based conservation scheme reduces the rate of illicit feeling and killing of wildlife the higher proportion was observed in villages around CWS (50.5\%) and lower in villages near DDWS (1.1\%). Farmers (66.7\%) than non-farmers (33.3\%, $\left.\chi^{2}=4.78, \mathrm{df}=1, p=0.029\right)$ and immigrant $(84.3 \%)$ than local people $\left(15.7 \%, \chi^{2}=14.099 ; \mathrm{df}=1 ; \mathrm{p}=0.0001\right)$ disagreed more with the perception about the role of community based conservation scheme that reduces the rate of illicit felling of trees and killing of wildlife.

\section{Effectiveness of community based conservation scheme:}

Nearly about two third of the respondents (62.3\%) disagreed about the effectiveness of community based conservation scheme protect biodiversity in their nearest PA and their opinions varied significantly between the study sites $\left(\chi^{2}=9.29, \mathrm{df}=1, p=0.002\right)$. Among the respondents who lived around the CWS (46.5\%) agreed more with the effectiveness of community based conservation scheme than those of respondents lived near the DDWS (21.2\%).

Table 7:- Results of linear regression showing the effects of demographic factors on the effectiveness of Comanagement for wildlife and forest into PA.

\begin{tabular}{|l|r|r|r|}
\hline \multirow{2}{*}{ Independent variables } & \multicolumn{3}{|c|}{ Effectiveness of commity based PA conservation and management } \\
\cline { 2 - 5 } & $\mathbf{R}$ & $\mathbf{t}$ & $\boldsymbol{p}$ \\
\hline Household size & 2 & -1.93 & 0.055 \\
\hline Income & 1 & 3.781 & 0.0001 \\
\hline Occupation & 5 & 0.933 & 0.352 \\
\hline Settlement status & 4 & 1.152 & 0.251 \\
\hline Education & 3 & -1.609 & 0.11 \\
\hline Age & 6 & -0.416 & 0.678 \\
\hline Constant & 1 & -0.12 & 0.904 \\
\hline $\mathrm{R}^{2}$ & & 0.088 & 0.0001 \\
\hline
\end{tabular}

A step wise linear regression analysis examining variations in perception on the effectiveness of community based conservation of PAs as dependent variable was tested with six independent variables. Income of the household was the only variable contributed significantly with this perception. The analysis showed that financially poor respondents expressed less effectiveness of community based conservation of PA than that of financially solvent respondents. All independent variable explained $8.8 \%$ of the variation in people's perception towards the effectiveness of community based PA management (Table 7).

\section{Discussion:-}

The forests in Bangladesh cannot fully meet local requirements for firewood because of a high level of human population growth and their dependency on forest resources as well as land for their livelihood (Akhter and Sarker 1998). Peoples' perceptions related to benefits and problems received from protected areas vary with their socioeconomic status. Both local people and immigrant people depend on timber and firewood for their livelihood that 
degrades the forest resources dramatically. The present study showed that local people received large amount of benefit from the collection of timber and firewood than immigrant. The reason behind the observation is that local people around the PAs depend on the park for timber and firewood from generation to generation. The distance the people live from a park boundary is an important factor controlling the degree of benefits they derive from that area with regard to the collection of timber and firewood (Sarker and Røskaft 2010). The similar findings observed in the present study. For instance, the respondents of Kolaharia village reported large amount of benefit from collection of timber and fire wood as it is relatively closer to the DDWS from other villages. Closer proximity to a park makes such an area more attractive for extracting resources illegally and thus the poor immigrant people live closer to the PA in most cases (Sarker and Røskaft 2010). Therefore, most of the community based conservation projects funded by different donors implemented their varieties of interventions closer to the park boundary. For example, to halt the degradation of timber and firewood from the PA, Nishorgo Support programme provides training to the people who lived closer to the park boundary in order to reduce their dependency on park resources for their livelihood. Thus, the present study observed that the immigrant people received large amount of benefit from information and training on wildlife and nature compared to the local people. Financial status is another important factor that shapes the variation in perceptions among respondents related to the different kinds of benefits of PAs such as benefit from timber and firewood, training \& information on wildlife and nature. The present study explored that the poor people received higher level of benefit from timber and fire wood extraction as they live close to the PAs and largely depended on the resources extracted from the forest (Sarker and Røskaft 2010). Education and age of the people in question are also important in forming differences of perceptions with regard to benefits as the young and illiterate people also expressed higher level of benefit than those of old and literate people from the perception related to the benefit of training and information on wildlife and nature. The respondents who resided around the CWS reported more benefits of financial incentives and soft credit, training and information on wildlife and nature and sound environment and tourism business than those respondents resided around the DDWS. This is because most of the community based conservation schemes have been executed in the CWS and provide awareness and motivation to the park surrounded people through training and education which made them conscious about the importance of nature and wildlife. As a consequence, their dependency on park for firewood and timber also reduced.

The villagers living closer to the park complained more of problems with crop raiding, destruction of houses, and fear of attack by wild elephants compared to those living farther away from a park boundary (Sarker and Røskaft 2011). The present study also showed that the villagers of Dudhpukuria and Jumpara which are relatively closer to the park faced higher level of crop raiding problem caused by the wildlife. Crop raiding by wildlife was the major problem in the study areas as reported by the respondents and their perceptions vary mostly with the financial and settlement status of respondents. Poor immigrant people lived closer to the park boundary and for this, they faced more crop raiding problems due to different crop raiders which include wild elephants, wild boar, porcupine, birds, rats etc. (Sarker and Røskaft 2011). Therefore, they expressed their inability to control the crop damage that form their negative attitude towards crop damage, which ultimately causes the conflict between human and wildlife, especially with wild elephants. The attitude of the respondents of DDWS was mostly negative to the conservation program compared to the CWS. DDWS is newly declared as wildlife sanctuary. That is why the people of this area are not habituated with the regulations and restrictions of the park management which already have grown up among the respondents of CWS.

Mosojane (2004) proved that seasonal fluctuations in crop raiding coincide with food availability and crop maturity. Crop damage caused by wild elephants occurred all time of the year in DDWS while in CWS it is mainly observed during the dry season. In DDWS, elephants raid fruits and vegetables beside the rice which are found all around the year. But in CWS, farmers practice rice mostly than those of other crops. That's why the attack takes place all around the year in the villages around the DDWS (i.e. Napitpukuria and Dudhpukuria) and during the dry season (at the time of crop ripping) in the villages surrounding the CWS (mostly in PoschimBrindabon).

Human-wildlife conflict is increasing mostly in the CWS compared to the DDWS as the attack of elephant is more in this area. People of PoschimBrindabon village support this statement mostly because they have to face more attack from the wild elephants at the time of taking protection measure.

In this study, majority of the respondents agreed that community based park conservation and management is not effective although they agreed that such conservation scheme can improve the regeneration status of plant species, which indicates their lower dependency on park resources. Levels of education or specific knowledge about conservation are positively correlated with more favourable attitudes towards nature conservation (Infield 1988; 
Newmarket al. 1993). In this study, majority of literate people agreed with the statements which were used to measure the role of participation in the management of wildlife and forest such as improvement of regeneration status of forest plans, reducing the rate of illicit felling of trees and killing of wildlife etc. Poor people expressed lower effectiveness of community based park conservation and management. Though they are included in the forest user groups, their decisions were always neglected by the village leaders and in the most they were excluded from the decision making process (Sarker and Røskaft 2010). Therefore, the top-down approach needs to change, involving resource users at every stage of management to ensure positive outcomes for all parties and enhancement of benefits to the villagers from the conservation activities of park management (Akhter and Sarker 1998).

\section{Conclusion and Future Prospects: -}

The people who lived near protected areas in Bangladesh were generally poor, and their perceptions towards conservation varied and depended on a variety of factors. These people were generally reluctant towards conservation. However, the people who lived near the CWS were a bit more positive towards conservation than those of the DDWS. The two most important variables explaining the attitudes of the respondents towards conservation were the distance they lived from the protected areas, their settlement and financial status. Immigrant people who are poor and who live closer to the protected areas disliked the conservation measures most.

However, the conflicts between humans and wildlife are mainly associated with the crop raiding behaviour of wildlife. Wildlife, particularly elephants, tramples crop fields in seasonal raids that coincide with crop maturity and food availability. DDWS is more vulnerable to crop damage by wild elephants and other wildlife than the CWS. Very few people were able to control damage caused by wildlife and thus the affected people were frustrated towards park conservation. Habitat degradation and fragmentation, the foremost important factors in wildlife conservation, are increasing in Bangladesh, a rustic that features a large population and a high rate of growth. These factors pose a challenge not only for the conservation of park also for wildlife in general, which is impossible to control. Conservation attitudes towards park conservation across the study areas are influenced mainly by the distances of human settlements from park boundaries.

Co-management settings may consider as one of one of the most effective ways to mobilise conservation. There is a requirement to adopt a decentralised deciding process that involves all stakeholders at a grassroots level to manage nature conservation. Socio-economic and demographic factors, such as education and level of income, may build the capacity to support conservation in protected. The sustainable conservation and management of park depends on the development of a scheme to compensate farmers adequately for the damages they suffer because of raids by different wildlife.

\section{Future Prospects:}

The main problem in the villages adjacent to the PAs is the crop raiding by animals especially by wild elephants. This crop raiding intensity varies with the season. The crop raiding is occurred due to the scarce of foods in the forest areas and the settlement of human-beings in the habitat range of different wildlife. The shortage of food is somewhat caused by the illegal settlement of people in the PAs by clearing forests for cultivation and development of infrastructure. Thus, wild animals are forced to forage in non-PAs and the disturbance to the local people is increased (Sarker and Røskaft, 2011). Therefore, to reduce such kind of assault it is important to increase the store of plant species in the forest. It can be done by relocating people outside the PA by state-sponsored and voluntary settlement (Sarker and Røskaft 2010). If it is impossible, then thoughtful land use strategies by Community-Based Natural Resources Management Schemes (CBNRMS) (O'Connell-Rodwelletal. 2000) can be taken. Another strategy is to make the cultivated areas less desirable to the problem animals, for example wild elephants by cultivating chillies, tobacco, tea, coffee etc. (Chiyoet al. 2005, Osborn and Parker 2003, Sarker and Røskaft 2011) instead of the palatable crops such as rice.

It is important to make people positive to the PAs or co-management program to conserve forest as well as wildlife. It can be done by providing compensation to the people for crop damage and by improving management-people relationships in conservation (Newmarket al. 1993, Wang et al. 2006). But in Bangladesh, most of the people think that co-management approach is not so effective in this purpose. It is for the biasness of the village leaders in the selection of stakeholders where poor and landless people are totally neglected. Their voice is always ignored in the decision making process. Moreover, members are dissatisfied with the amount of support and lack of financial incentives for alternative income-generating activities provide by Nishorgo Support Project (Sarker and Røskaft 2010). Such supports are also determined without effective discussion and negotiation of options with the true 
stakeholders (Kidegheshoet al. 2007). For this, Sarker and Røskaft (2010) felt that in accordance with good governance principles the systems of PAs should be consolidated, expanded and improved where the rights, interests and concerns of all stakeholders will be respected and their participation in decision making in establishment and management of PAs must be ensured. They also suggested that the sharing of protected area ownership, responsibilities, costs and benefits should be distributed with appropriate negotiation among relevant bodies or groups i.e. disadvantaged people. These will help to strengthen the engagement of general people in conservation programs.

\section{References: -}

1. Agarwal, A. andOstrom, E. (2001) Collective action, property rights, and decentralization in resource use in India and Nepal. Politics \& Society29(4):495-514.

2. Akhter, S. andSarker, A.H.M.R. (1998) Patronage, tenure, inclusiveness and local markets: ingredients of a successful strategy for social forestry at Betagi. For Trees People Newsletter. 35: 36-41.

3. Conover, M.R. (2002) Resolving Human-wildlife Conflicts. The Science of Wildlife Damage Management. New York: CRC Press, LewisPublishers.

4. Gadgil, M. (1990) India's deforestation: patterns and processes. Society and Natural Resources 3: 131-143.

5. Gilbert, D. L. (1971) Natural Resources and Public Relations, Department of Conservation, CornellUniversity, Ithaca, New York.

6. Greenough, P. (2003) Pathogens, pugmarks, and political emergency: The 1970s South Asian debate on nature. See Greenough \& Tsing, 2003. pp. 201-30.

7. Heinen, J.T. (1993) Park-people relations in KosiTappu Wildlife Reserve, Nepal: a socio economic analysis. EnvironmentalConservation 20: 25-34

8. Hill, G.M. (1998). Conflicting attitudes towards elephants around the Budongoforest reserve, Uganda. Environmental Conservation. 25: 244-250.

9. Hoare, R. (2000). African elephants and humans in conflict: the outlook for co-existence. Oryx 34: 34-38.

10. Horowitz, L.S. (1998) Integrating indigenous resource management with wildlife conservation: a case study of Batang Ai National Park, Sarawak, Malaysia. Human Ecology26(3):371-403

11. Igoe, J. (2003) Scaling up civil society: donor money, NGOs and the pastoralist land rights movement in Tanzania. Development and Change 34:863-85

12. Infield, M. (1988) Attitudes of a rural community towards conservation and a local conservation area in Natal, South Africa. Biological Conservation 45: 21-46.

13. Jim, C.Y.and Xu, S.S. (2003) Getting out of the woods: quandries of protected area management in China. Mountain Research and Development. 23:222-26

14. Khan, M.A.S.A., Uddin, M.B., Uddin, M.S., Chowdhury, M.S.H. \&Mukul, S.K., 2007. Distribution and status of forests in the tropics: Bangladesh perspective. Proceedings of the Pakistan Academy ofSciences. 44(2): 145153.

15. Kharel, F. R. (1997) Agricultural crop and livestock depredation by wildlife in Langtang National Park, Nepal. Mountain Research and Development 17(2):127-134.

16. Kideghesho, J.R.E., Røskaft, E. andKaltenborn, B.P. (2007). Factors influencing conservation attitudes of local people in Western Serengeti, Tanzania. Biodiversity and Conservation. 16(7): 2213-2230.

17. Limbu, K.P. and Karki, T.B. (2003) 15 Park-people Conflict in KoshiTappu Wildlife Reserve. Our Nature 1: 15-18 Central Department of Zoology, TribhuvanUniversity, Kathmandu.

18. Mahanty, S. (2003) Insights from a cultural landscape: lessons from landscape history for the management of Rajiv Gandhi (Nagarahole) National Park. Conservation and Society. 1(1):23-45

19. Maikhuri, R.K., Nautiyal, S., Rao, K.S. andSaxena, K.G. (2001) Conservation policy-people conflicts: a case study from Nanda Devi Biosphere Reserve (a World Heritage Site), India. ForestPolicy and Economics 2: 355365.

20. McLean, J., Straede, S. (2003) Conservation, relocation and the paradigms of park and people management - a case study of Padampur Villages and the Royal Chitwan National Park, Nepal. Soc. Nat. Res. 16:509-26

21. McNeely, J.A. andScherr, S.J. (2003) Ecoagriculture: Strategies to feed the world and save biodiversity, Chapter 3. Agriculture and human welfare, pp. 31-50. Washington, Covelo, USA/London, UK: Island Press: $323 \mathrm{pp}$.

22. Mehta, J.N. and Kellert, S.R. (1998) Local attitudes toward community-based conservation policy and programmes in Nepal: a case study in the Makalu-BarunConservationArea. EnvironmentalConservation 25: 320-333. 
23. Mishra, S.N. (1984) Book Reviews. Indian Journal of Public Administration; 30(4):1162-1163. doi: $10.1177 / 0019556119840428$

24. Mishra, C. (1997) Livestock depredation by large carnivores in the Indian trans-Himalaya: conflict perceptions and conservation prospects. Environmental Conservation 24(4):338-343

25. Mordi, A.R. (1991) Attitudes Toward Wildlife in Botswana.NewYork, NY, USA: Garland Publishing, Inc.

26. Mosojane, S. (2004) Human-Elephant Conflict in the eastern Okavango Panhandle. MSc Thesis. University of Pretoria.

27. Negi, C.S., and Nautiyal, S. (2003) Indigenous peoples, biological diversity and protected area managementpolicy framework towards resolving conflicts. Int. J. Sustain. Dev. WorldEcol. 10:169-79

28. Nelson, J., and Hossack, L. eds. (2003)Indigenous Peoples and Protected Areas in Africa. Moreton-in- Marsh, UK: Forest Peoples Programme

29. Nepal, S.K. and Weber, K.E. (1995) Prospects for coexistence: wildlife and local people. Ambio24: 238-245.

30. Newmark, W.D., Leonard, N.L., Sariko, H.I., and Gamassa, D.M., 1993. Conservation attitudes of local people living adjacent to five protected areas in Tanzania. Biological Conservation 63, 177-183.

31. Nyphus, J.P., Tilson R, and Suminato (2000) Crop-raiding elephants and conservation implications at Way Kambas National Park, Sumatra, Indonesia. Oryx (34)4. P.262-274.

32. O'Connell-Rodwell CE, Rodwell, T., Rice, M., and Hart, L.A. (2000) Living with the modern conservation paradigm: can agricultural communities co-exist with elephants? A fiveyear case study in East Caprivi, Namibia. BiolConserv. 93:381-391.

33. Panusittikorn, P., and Prato, T. (2001) Conservation of protected areas in Thailand: the case of KhaoYai National Park. Protected Areas East Asia 18(2):67-76.

34. Paudel, N.S. (2005) Conservation and livelihoods: an exploration of the local responses to conservation interventions in Royal Chitwan National Park in Nepal. PhD thesis. University of Reading, UnitedKingdom

35. Roth, R. (2004) On the colonial margins and in the global hotspot: park-people conflicts in highland Thailand. Asia Pacific Viewpoint45(1):13-32

36. Saberwal, V.K., Gibbs, J.P., Chellam, R. andJohnsingh, A.J.T. (1994) Lion-human conflict in the Gir Forest, India. Conservation Biology8: 501-507

37. Santana, E.C. (1991) Nature conservation and sustainable development in Cuba. Conservation Biology, $5(1): 13-17$

38. Sarker, A., and Røskaft, E. (2011). Human attitudes towards the conservation of protected areas: A case study from four protected areas in Bangladesh. Oryx, 45(3), 391-400. doi:10.1017/S0030605310001067

39. Sarker, R. andRøskaft, E. (2010). Human-wildlife conflicts and management options in Bangladesh, with special reference to Asian elephants (Elephasmaximus). International Journal of Biodiversity Science. Ecosystem Services \& Management. 164-175. doi:10.1080/21513732.2011.554867.

40. Straede, S. and Helles, F. (2000), Park-people conflict resolution in Royal Chitwan National Park, Nepal: buying time at high cost?

41. Studsrod, J.E. \&Wegge, P. (1995) Park-people relationships: the case of damage caused by park animals around the Royal Bardia National Park, Nepal. Environmental Conservation 22: 133142.

42. Sukumar, R. (1989) The Asian elephant - ecology and management. Cambridge University

43. Press, Cambridge, UK.

44. Thouless, C.R. (1994) Conflict between human and elephants on private land in northern Kenya. Oryx. 28: 119127.

45. Wang. S., Lassoie. J, and Curtis, P. (2006) Farmer attitude towards conservation in jigmesingyewangchuk national park, Bhutan. Environmental conservation, 38, 148-156.

46. West P., Igoe. J. and Brokington D. (2006) Park and People: the social impact of protected area.

47. West, P., Igoe, J. and Brockington, D. (2008) Parks and Peoples: The Social Impact of Protected Areas. Annual Review of Anthropology. 35. 10.1146/annurev.anthro.35.081705.123308.

48. Wikipedia, the free encyclopedia, 2013.

49. Wilshusen, P., Brechin, S.R., Fortwangler, C. and West, P.C. (2002) Reinventing a square wheel: a critique of a resurgent protection paradigm in international biodiversity conservation.

50. Society and Natural Resources 15:17-40

51. Woodroffe, R. and Ginsberg, J.R. (1998) Edge effect and the extinction of populations inside protected areas. Sciences. 280: 2126-2128.

52. Woodroffe, R., Thirgood, S. andRobinowitz, A. (eds) (2005) People and wildlife conflict or coexistence? Cambridge University press, Cambridge, UK. 